\title{
TRABALHO E EDUCAÇÃO NA CONSTRUÇÃO DA RUSSIA SOCIALISTA
}

\author{
Vanderlei Amboni \\ Universidade Estadual do Paraná - Campus de Paranavaí - UNESPAR \\ Luiz Bezerra Neto \\ Maria Cristina dos Santos Bezerra \\ Universidade Federal de São Carlos - UFSCAR
}

\begin{abstract}
RESUMO
O presente trabalho é um estudo do projeto educacional comunista para a construção da Rússia socialista. Sua base é o texto "A educação na Rússia Revolucionária" de Anatoli Lunatcharski, que foi designado como comissário do povo para a cultura e educação no primeiro governo da URSS. Nosso objetivo é mostrar a construção da escola do trabalho e sua vinculação com a sociedade socialista na busca da omnilateralidade do homem. Neste sentido, a organização da vida escolar está vinculada ao trabalho produtivo e à formação dos valores do homem comunista. Portanto, a produção da vida material e a organização do modo de produção comunista são partes constitutivas do ser omnilateral. Essas são as premissas básicas da escola do trabalho. Assim, teóricos da educação comunista, como Krupskaia, Lunatcharski, Pistrak, etc, procuraram criar e fundamentar a nova escola centrada no trabalho coletivo. Nascia, com isso, a pedagogia socialista.

Palavras-chave: Escola do trabalho; Educadores socialistas; Formação Politécnica; Emulação.
\end{abstract}

\section{WORK AND EDUCATION IN SOCIALIST CONSTRUCTION OF RUSSIA}

\begin{abstract}
The present work is a study of the educational project for the construction of communist socialist Russia. Its basis is the text "Education in Revolutionary Russia" Anatoli Lunacharsky, who was appointed people's commissar for culture and education in the first government of the USSR. Our goal is to show the construction of the school's work and its relationship with the socialist society in search of omnilateralidade man. In this sense, the organization of school life is linked to productive work and training values of communist man. Therefore, the production of material life and organization of the communist mode of production are constitutive parts of omnilateral be. These are the basic premises of the school's work. Thus, education theorists communist, as Krupskaya, Lunacharsky, Pistrak, etc., sought to create and support the new school centered on collective work. Born with that, socialist pedagogy.
\end{abstract}

Keywords: School work. Educators socialists. Training Polytechnic. Emulation.

\section{Introdução}

O artigo que apresentamos é esboço de uma discussão sobre trabalho e educação na formação da Rússia Revolucionária. Não vamos analisar o trabalho em sí, isto é, como os homens produzem a sua vida material. O que pretendemos analisar é o processo de trabalho e educação como formação do homem comunista na fase leninista de organização social. Fase esta de construção e disseminação da cultura comunista como elemento essencial da formação do novo homem, frente à cultura burguesa. A educação, neste 
sentido, é a arma ideológica do partido para fins de organização da sociedade comunista. Instruir os operários, os camponeses e a juventude foi a tarefa que o Partido Comunista Russo desenvolveu como política fundamental para edificar o homem comunista. Não é por acaso que Lenin afirmou que "Nosso lema absoluto será menos direção e mais ações práticas" (LENIN, 1977a: 69). Criar a escola socialista é vencer a indisciplina pequenoburguesa.

Neste aspecto, discursando no I Congresso do Ensino Extra-Escolar da Rússia, em 1919, Lenin (1977b: 122) se manifestou afirmando que:

[...] Esta nova organização de Estado nasce no meio de grandes esforços, porque vencer a nossa indisciplina pequeno-burguesa desorganizadora é o mais difícil de tudo, um milhão de vezes mais difícil que esmagar o opressor, latifundiário ou capitalista, mas resulta também um milhão de vezes mais frutuoso para a criação de uma organização nova, livre de exploração. Quando a organização proletária conseguir vencer esta tarefa, o socialismo terá triunfado definitivamente. A isto se deve consagrar toda a atividade, tanto a extra-escolar, como no escolar [...].

A palavra de ordem era promover a educação na Rússia revolucionária. Assim, neste artigo, analisaremos os estudos realizados por Nadezhda Krupskaia, Anatoli Lunatcharski, Moisey Mikhaylovich Pistrak, que participaram efetivamente da construção da escola do trabalho, além de pesquisadores como Saviani, Frigotto e Lombardi que há muito vem contribuindo com a discussão do trabalho como principio educativo, tal qual foi formulado por Marx.

Nosso artigo está dividido em duas partes. Na primeira, analisaremos os problemas enfrentados pela revolução na construção da pedagogia comunista alicerçada no pressuposto estabelecido por Marx. Na segunda parte, a discussão está centrada na criação da escola do trabalho, alicerçada na politecnia. Trabalho e educação é a matriz ontológica do homem. Trabalho e educação são um determinante do homem no seu devir histórico, pois o trabalho é um ato intencional do homem que necessita produzir sua vida material e, nesse processo, ele extrai da natureza, ativa e intencionalmente, os meios de sua existência. Ele inicia o processo de transformação da natureza e cria o mundo humano. A educação é um fenômeno próprio do homem e isto significa que ela é, ao mesmo tempo, uma necessidade do e para o processo de trabalho, bem como é, ela própria, um processo de trabalho (SAVIANI, 2011: 11). É sobre isso que apresento o presente trabalho.

\section{Da revolução à ação pedagógica.}

[...] Construir el socialismo no significa unicamente elevar la produtividade del trabajo y desarrollarla economia. Una economia social desarrollada no es más que la base, el fundamento, que hace posible el bienestar general. La esencia de la construcción del socialismo reside en una organización nueva de todo el tejido social, en un nuevo regimen social, en nuevas relaciones entre los hombres. Queremos construir una vida holgada y almismo tempo luminosa (KRUPSKAIA).

A Revolução Russa, de 1917, engendrada e consagrada pelas forças populares comunistas apontaram para uma construção social com base no socialismo, isto é, uma sociedade onde a propriedade privada se torna propriedade coletiva e proclama o fim das classes sociais. À jovem nação socialista que nascia, precisava provar sua capacidade de organização para além da teoria marxista. Precisava criar as bases que dará sustentação e consistência política às ações do Estado Socialista e da ditadura do proletariado e dar 
respostas ao mundo, pois a tomada do poder, pelos bolcheviques, abalou o mundo. Este fato é, até então, impar na história dos homens. Mas a Rússia, no processo de construção do socialismo, se via à frente de graves problemas políticos e sociais, externo e internamente. Externamente, tem o cerco das nações capitalistas e o fechamento das fronteiras russas para sufocar a revolução e, internamente, a pobreza extrema, o analfabetismo crônico do povo russo e a guerra civil. Construir, portanto, o socialismo na Rússia, sob as condições de miséria social, analfabetismo, cerco imperialista, forte concentração da propriedade da terra e uma incipiente industrialização exigiria dos comunistas russos um rompimento brutal das relações sociais capitalistas para forjar, sob novas relações de trabalho e educação, um novo tipo humano para a criação da sociedade do futuro, isto é, a sociedade comunista. Não é a toa que Pistrak (2003: 30) afirmou que "a revolução e a escola devem agir paralelamente, porque a escola é a arma ideológica da revolução".

Neste aspecto, Lenin não se descuida da juventude e, sempre que pode, procura desenvolver a emulação entre os jovens, incentivando-os a estudarem para que a sociedade comunista possa emergir dos escombros da velha sociedade burguesa. Nesse sentido, ressalta os valores culturais que a humanidade, até então produziu no seu devir histórico.

Por isso, Lenin (1977a: 122), afirma que a "tarefa principal da juventude é 'aprender'" e pontua que:

Não podemos edificar o comunismo senão a partir da soma de conhecimentos e forças humanas que herdamos da velha sociedade. Só transformando radicalmente a ensino, a organização e a educação da juventude conseguiremos que o resultado dos esforços da jovem geração constitua a criação de uma sociedade que não se assemelha à antiga ou seja, da sociedade comunista.

Para tanto, o Programa do Partido Comunista Russo - PCR, no tocante à instrução pública, ressaltou a importância de "transformar a escola de arma de dominação de classe da burguesia, em arma de derrube dessa dominação, assim como a supressão total da divisão da sociedade em classes". Para isso, a "escola deve converter-se em arma da ditadura do proletariado, ou seja, não só em veículo dos princípios do comunismo em geral, mas também da influencia ideológica, organizativa e educativa do proletariado [...] e realizar o regime comunista" (LENIN, 1977a: 116). É a construção da escola do trabalho como processo de identidade comunista, portanto, de uma sociedade que se fundará na omnilateralidade do trabalho.

Não é por acaso que Lombardi (2011: 106) afirma que:

No processo revolucionário, portanto, a educação é um importante instrumento para que o trabalhador consiga não apenas ter acesso aos conhecimentos, mas que, a partir deles, possa controlar o processo de produção e reprodução dos conhecimentos científicos e técnicos envolvidos no processo produtivo.

Em uma carta do jovem Marx, endereçada a Ruge, em 1843, assim se expressava: "O mundo burguês constitui o domínio político da animalidade, o mundo desumanizado. [...] Deixemos os mortos sepultarem os mortos e chorá-los. O que é, por um lado, invejável é sermos os primeiros a entrar vivos numa vida nova, este deve ser o nosso destino" (MARX apud GARAUDY, 1967: 47) Entrar vivos numa nova vida, eis o que os bolcheviques fizeram. Portanto, construir a sociedade socialista em uma realidade social com forte presença do latifúndio e de miséria social no campo e na cidade, aliada à presença do analfabetismo crônico entre a população russa, passou a ter emergência na 
práxis revolucionária. Trabalho e educação, neste aspecto, passaram a ser fundamental na orientação socialista para a construção da nova sociedade. As bases teóricas estavam em evidência. $\mathrm{O}$ foco agora era traduzir os aspectos teóricos em ações concretas e transformar a Rússia, um misto de capitalismo/feudalismo, em um país socialista, posto que, os filósofos até então não fizeram senão interpretar o mundo de diferentes maneiras, mas trata-se de transformá-lo, conforme nos ensina Marx. E Lenin poderia, assim, concluir a frase: e, essa tarefa cabe agora a nós, comunistas russos.

Partindo das premissas educacionais básicas de Marx (1975: 51), que apontou nas instruções aos delegados do Conselho Central Provisório da Associação Internacional dos Trabalhadores, que, "Numa sociedade racional, qualquer criança, desde os nove anos de idade, deve ser um trabalhador produtivo, tal como um adulto na posse de todos os seus meios não se pode eximir à lei geral da natureza, segundo a qual aquele que quer comer tem também de trabalhar não só com o cérebro, mas também com as mãos". Como processo de proteção à criança, aliando trabalho/educação, julga útil dividi-la em três categorias, com tratamentos diferenciados entre si e, aqui, cito Marx (1975: 51), a saber:

A primeira compreende as crianças dos 9 aos 12 anos; a segunda, as dos 13 aos 15 anos; a terceira, as dos 16 aos 17 anos. Propomos que o emprego da primeira, em qualquer trabalho, na fábrica ou no domicílio, seja legalmente restringida a duas horas; o da segunda a quatro horas e o da terceira a seis. Para a terceira deverá haver uma interrupção de uma hora pelo menos para a refeição e recreio.

Salientamos que essas propostas se inserem no quadro do século XIX, onde o trabalho estava submetido à extrema exploração por parte do capital, levando a exaustão e a degradação do corpo e da mente da criança e do adolescente que só trabalha. Por isso, Marx insiste que trabalho e educação, sob o capitalismo, deve haver uma alternância entre sí, como meio de desenvolver o intelecto da criança e do adolescente trabalhador, frente à brutalidade e exploração do trabalho que ele está submetido.

Por isso, Frigotto (1989: 25) afirma que:

[...] O trabalho na perspectiva materialista, deve estar presente deste a infância. Isto decorre do fato de que ninguém deve subtrair-se ao cumprimento da 'lei da natureza' em que o homem, para sobreviver e produzir-se, precisa transformar a natureza para satisfazer suas necessidades. Por essa razão, Marx e Engels veem na tendência da sociedade industrial nascente de incorporar as crianças de ambos os sexos na produção social como algo procedente, progressista e legitimo, embora, sob o capitalismo isto se torne um processo de alienação, exploração e flagelo.

Por isso, Marx sai em defesa da criança e do adolescente quando coloca o termo "seja legalmente restringida" às horas de trabalho, conforme apontada nas Instruções para cada segmento, quer seja no trabalho realizado na fábrica, quer no domicílio, pois este se tornou uma "extensão" da fábrica. A luta era, portanto, para conciliar trabalho e educação, posto que a sociedade capitalista não abria mão do emprego da força produtiva dos jovem trabalhador, bem como da mulher, como forma de coerção sobre o trabalhador adulto. Nesse sentido, Marx (1975: 52) diz que "a sociedade não pode permitir nem aos pais nem aos patrões que empreguem no trabalho as crianças e os adolescentes, a menos que combinem o trabalho produtivo com a educação" e lança o que entende por educação, centrada em três princípios, conforme expõe Marx (1975: 52), a saber: 
1. Educação intelectual;

2. Educação corporal, tal como é produzida pelos exercícios ginásticos e militares;

3. Educação tecnológica, abarcando os princípios gerais e científicos de todos os processos de produção e ao mesmo tempo iniciando as crianças e os adolescentes no manejo dos instrumentos elementares de todos os ramos da indústria.

Neste caso, Lombardi (2011: 226) afirma que “A educação proposta, longe de orientar uns para uma profissão e outros para outra, deveria se destinar a todas as crianças e jovens, indistintamente, possibilitando tanto o conhecimento da totalidade das ciências, como das capacidades práticas em todas as atividades produtivas". Ou seja, uma educação que busca a omnilateralidade no processo constitutivo do homem. Esse princípio, Marx definiu partindo das leituras de Robert Owem, que aqui cito:

[...] Do sistema fabril, conforme expõe pormenorizadamente Robert Owen, brotou o germe da educação do futuro, que conjugará o trabalho produtivo de todos os meninos além de uma certa idade com o ensino e a ginástica, constituindo-se em método de elevar a produção social e de único meio de produzir seres humanos plenamente desenvolvidos (MARX apud LOMBARDI, 2011: 226-227).

Portando, o desenvolvimento das forças produtivas e da maquinaria, enquanto processo de produção, tem n ciência seu centro propulsor de desenvolvimento tecnológico. O espaço de aplicação da ciência, potencializada na maquinaria, é a fábrica, o que possibilita processos de trabalho e educação. Marx centra suas atenções no processo de produção e se atém à base educacional que permite o processo de formação omnilateral do homem, conforme aponta Lombardi (2011: 227). Para Frigotto (1989: 25) "A omnilateralidade se contrapõe ao reducionismo histórico do homem unilateral, o 'homo economicus'. Homem formado, educado, treinado para desenvolver traços funcionais do mercado". O que é, portanto, a omnilateralidade do homem? Aqui cito Frigotto (1989: 25):

A concepção de omnilateralidade do homem centra-se na apreensão do homem enquanto uma totalidade histórica que é, ao mesmo tempo 'natureza', individualidade e, sobretudo, relação social. Uma unidade na diversidade física, psíquica e social; um ser de necessidades imperativas (mundo da necessidade material) em cuja satisfação se funda suas possibilidades de crescimento em outras esferas (mundo da liberdade) (FRIGOTTO, 1989: 25).

Os fundamentos da educação omnilateral têm, portanto, como ponto de partida a fábrica. A fábrica é, nesse sentido, o "locus" potencializado da ciência e do desenvolvimento das forças produtivas.

Não é por acaso que Lombardi (2011: 227) vai afirmar que:

Os fundamentos dessa educação omnilateral e politécnica era uma decorrência da própria transformação da indústria que constantemente revoluciona as bases técnicas da produção e com ela a divisão do trabalho. Articulando o desenvolvimento das forças produtivas com a implementação de transformações nas bases técnicas de produção, cujas dimensões promovem transformações na divisão do trabalho, é que Marx vislumbrou uma educação mais ampla, integral e flexível.

Trabalho e educação são, portanto, elementos constitutivos da nova ordem social, assentada na propriedade coletiva dos meios de produção, dadas pela Revolução Russa. 
Neste aspecto, o poder soviético inicia os trabalhos buscando no trabalho e na educação, romper com a construção ideológica da velha estrutura senhorial russa. Com um discurso contundente, produzido no decreto sobre a educação popular, Lunatcharski, (1917) assevera que "mediante la insurrección del 7 de noviembre, las masas trabajadoras han conquistado auténticamente el poder por primera vez en la historia". Traz para a realidade a conquista do poder político e, com ele, a necessidade de construir um novo tipo de homem. Mas, para esse fim, cumpre vencer os obstáculos à formação da juventude comunista e, consequentemente, do homem socialista.

O processo de formação da juventude na Rússia revolucionária se esbarrava nas dificuldades encontradas na própria realidade, a saber: a falta de estrutura física, ou seja, de escolas e de pessoal qualificado para sua efetivação. A realidade educacional que Lunatcharski encontrou foi um "reino de analfabetismo" gritante, fruto da política de classe desenvolvida pelo regime tzarista, pois:

O primeiro objetivo que se coloca o governo da classe dominante consiste em manter o atraso das massas, para abafar todo o pensamento crítico. Quando se trata de um país como a Rússia, o ministro da Instrução Pública foi até o fim do regime czarista, segundo a expressão de Chtchedrine, ministro do obscurantismo público. Se uma sociedade quiser abrir uma escola, o ministro não dará autorização; Quando se quiser abrir uma universidade numa cidade, o ministro opor-lhe-á uma recusa; se um professor for talentoso, será exilado para o estrangeiro; se os estudantes lutarem para que a escola dê mais tempo aos estudos científicos, mandam-se para a tropa. Foi esta a constante da política do Ministério da Instrução Pública que era uma espécie de departamento do Ministério do Interior. Este velava por conservar a sua preponderância sobre a escola (LUNATCHARSKI, 2002b: 04).

Lunatcharski (2002b: 12), no I Congresso de Toda a Rússia para a Instrução Pública, realizado em 1922, apontou que a escola ainda é, para muitos, uma realidade inacessível, conforme dados que ele apresentou em seu discurso, que aqui cito:

Sabeis que, globalmente falando, as nossas escolas do primeiro grau só podem receber metade das crianças, e que o segundo grau é apenas suficiente para 5 a $6 \%$ das crianças. Fica, pois, claro que cerca de nove pessoas em cada dez não podem, no término do primeiro grau, entrar para o segundo grau. E isso desfavorece enormemente a população rural em relação à urbana, o que destrói a própria unidade relativa da escola. Daí resulta que, apesar de tudo, um filho de camponeses terá, nessa qualidade, na maioria dos casos e independentemente das suas capacidades - isto na Rússia soviética, mesmo que à escola sejam garantidas as melhores condições nas próximas décadas após a revolução - muito menos possibilidades de ser admitido no segundo grau que a criança da cidade.

Para isso, Lunatcharski (1917) pontuou no decreto sobre educação que,

[...] en materia de educación, todo poder auténticamente democrático, en un país donde reinan el analfabetismo y la ignorancia, debe trazarse como primer objetivo la lucha contra estas dos plagas. Debe, dentro de los plazos más perentorios, acabar enteramente com el analfabetismo organizando una red de escuelas que responda a las exigencias de la pedagogía moderna e implantando la enseñanza general obligatoria y gratuita; debe, al mismo tiempo, crear toda una serie de escuelas normales y establecimientos que puedan, a la mayor brevedad, formar el 
poderoso ejército de maestros necesarios para instruir a toda la población de la inmensa Rusia [...].

Neste aspecto, a orientação geral da atividade educacional é vencer o analfabetismo e a ideologia burguesa transmitida e ensinada nas escolas através da educação cívica, pois a educação tzarista centrava-se no respeito à propriedade privada e no regime político. A luta pela desideologização burguesa da escola era tarefa de todos. Por isso, Krupskaia escreveu no Jornal Pravda, em 27 de maio de 1917, se contrapondo aos "pedagogos burgueses" que "hablan y escriben mucho sobre la necesidad de la 'educación' de la juventud, entendiendo por 'educación cívica' el respeto a la propiedad privada y el regimen politico existente [...]." e passou a pontuar a necessidade de uma nova orientação à educação cívica, garantindo, através dela, uma formação para a solidariedade proletária. Assim Krupskaia (1917), na construção da sociedade socialista assevera que a educação cívica trata "da la vida a los jovenes obreros. La vida les educa en el noble espiritu de la solidaridad proletaria de clase, hace que comprendan y amenla divisa: ‘Proletarios de todos los países, uníos!’ y los coloca en las filas de los luchadores ‘por un mundo fraternal y la sagrada libertad"'. A solidariedade, como tarefa da juventude comunista, portanto, é o chamado de Krupskaia para a ação e a construção de um novo tipo de homem. Assim, a solidariedade não é um ato mecânico e em defesa da propriedade privada. É uma solidariedade para promover a união fraternal dos trabalhadores e edificar a sociedade comunista, pois "em uma sociedade alforriada do capitalismo 'o livre desenvolvimento de cada um será a condição para o desenvolvimento de todos" (KRUPSKAIA apud LODICORREÊA; JACOMELI, s/d: 5).

Não é por acaso que o programa do PCR, sobre instrução pública, consta como tarefa imediata dos comunistas, "implementar a instrução geral e politécnica (que ensine a teoria e a pratica dos ramos mais importantes da produção) gratuita e obrigatória para todas as crianças de ambos os sexos menores de 16 anos" e "estabelecer laços estreitos entre o ensino e o trabalho produtivo social das crianças" (LENIN, 1977a: 117). As palavras de ordem do partido, em consonância com os postulados de Marx, aparecem na forma de trabalho e educação para a formação do homem omnilateral. Desenvolver, portando, as qualidades necessárias para o trabalho coletivo e, assim, consolidar a sociedade do trabalho, isto é, a sociedade comunista.

Para tanto, a escola do comunismo,

[...] é uma escola do trabalho. Entendemos por isso uma escola que, tanto quanto possível, renunciasse a todas as "lições", que desse à criança desenvolvendo ao mesmo tempo as suas capacidades - a possibilidade de se desenvolver brincando, passando pouco a pouco dos processos simples de trabalho aos cada vez mais complexos e produtivos que proporcionam conhecimentos práticos. Ao alimentá-la sempre com os seus próprios interesses, a escola terá mais a certeza de levar a criança para o círculo dos conhecimentos e aptidões práticas, porque são assimilados pelos órgãos externos de todo o organismo (LUNATCHARSKI, 2002b: 21).

Essa escola, portanto, é a escola do trabalho. No comunismo, a escola do trabalho tem que ser única e politécnica. Para esse fim, Krupskaia, Lunatcharski, Pistrak, dentre outros pedagogos russos se debruçaram para edificar a escola única do trabalho. 


\section{A escola proletária do trabalho: única e politécnica}

Nós precisamos criar uma escola que prepare os construtores da nova vida [...]. A tarefa iniciada vai ser agarrada pela juventude; é necessário que as mãos dela sejam mais hábeis, que os olhos sejam mais vigilantes, os movimentos confiantes. A escola deve ajudar a criar e fortalecer a nova juventude, deve formar os lutadores por um futuro melhor, os criadores dele [...]. É preciso dar os primeiros passos, depois observar atentamente, tatear o campo para o futuro, ver com olhos abertos, não fechar os olhos aos erros, corrigi-los no processo de trabalho, criticamente relacionar-se com seu trabalho e o mais importante: observar, observar, observar... (KRUPSKAIA).

A sociedade fundada no trabalho, que emergiu das lutas de classes entre o proletariado e a burguesia na Rússia, necessitava criar as bases da educação socialista, tendo o trabalho como eixo norteador. A escola única do trabalho e a politecnia foram a resposta encontrada, pois o fundamento da existência do homem é o trabalho. Nele, há o processo de hominização do homem e em suas relações sociais, sua humanização. Neste sentido, o homem se faz homem pelo trabalho. Mas "o homem não vive para trabalhar, mas trabalha para viver humanamente. É nesta vocação da natureza humana que reside a sua divindade, a sua dignidade que o distingue do animal, porque o animal não é consciente". Neste sentido, "o homem é um trabalhador, e a natureza é o seu material. A sua finalidade é transformar a natureza segundo o seu ideal". Por isso, "as palavras de Marx eram ouro quando dizia: a ciência que nos precede tem interpretado o mundo de maneiras diferentes, o nosso objetivo é, porém, o de o transformar" (LUNATCHARSKI, 2002a: 05).

Não é por acaso que Lombardi (2011: 103) vem afirmar que:

$\mathrm{O}$ ato de agir sobre a natureza transformando-a em função das necessidades humanas é o que conhecemos pelo nome de trabalho. Podemos, pois, dizer que a essência do homem é o trabalho. Mas o sentido marxista de essência humana não é o da metafísica: como o conjunto das propriedades imutáveis e eternas do homem, como algo dado ao homem, uma dádiva divina ou natural. Ao contrário, a essência humana é usada no sentido de característica fundamental dos homens, sendo esta produzida pelos próprios homens. O que o homem é, o é pelo trabalho. A essência do homem é um feito humano. É um trabalho que se desenvolve, se aprofunda e se complexifica ao longo do tempo: é um processo histórico.

Neste processo, trabalho e educação são partes constitutivas da organização da vida social da humanidade no seu devir histórico. As relações sociais brotadas do trabalho, isto é, de como os homens produzem sua existência material determinam um conjunto de ações historicamente produzidas pelo homem, entre elas, a educação. O trabalho, portanto, tem uma dimensão educativa, posto que "trabalho e educação são atividades especificamente humanas. Isto significa que, rigorosamente falando, apenas o ser humano trabalha e educa" (Saviani, 2007: 152). Neste sentido, pensando como Marx, Frigoto (2009: 72) pontua que "o trabalho é princípio educativo porque é através dele que o ser humano produz a si mesmo, produz a resposta às necessidades básicas, imperativas, como ser da natureza (mundo das necessidades), mas também e não separadamente às necessidades sociais, intelectuais, culturais, lúdicas, estéticas, artísticas e afetivas (mundo da liberdade)”.

Frigotto, portanto, aponta que o "trabalho aparece aqui na sua dimensão positiva, como manifestação da vida, como forma de os homens se apropriarem e transformaram o 
mundo da natureza em si mesmos, em seu devir" e os elementos fundantes da escola única do trabalho, é a politecnia. Neste aspecto, Frigotto (1989: 25) pontua que "os elementos básicos e indissociáveis do conceito de politecnia, basicamente, são: a) a concepção de homem omnilateral; b) o trabalho produtivo e a articulação entre trabalho manual e intelectual; c) as bases científico-técnicas, comuns da produção industrial" (FRIGOTTO, 1989: 25).

Por isso, o discurso de Lunatcharski (2002b: 21), é muito salutar e cabe ser registrado:

Chamamos-lhe escola politécnica, porque não gostaríamos que o trabalho fosse estudado com base num só exemplo. Ao estudardes a história da fábrica, estais a estudar a evolução das relações de trabalho, aprendeis o que são as doenças profissionais, confrontar-vos-eis com a higiene social, a anatomia, a fisiologia - com as disciplinas médicas em geral. Não existe um grupo de conhecimentos que não esteja estreitamente ligado a essa gigantesca meada das relações entre o homem e a natureza, a esse nó que um grande centro industrial, uma fábrica ou uma oficina constituem $[\ldots]$.

Sob a revolução do trabalho se faz necessário criar a escola do trabalho, única, mas não uniforme, posto que as diferenças regionais e as relações entre campo e cidade são distintas entre si. Portando, as desigualdades regionais são manifestas. A escola do trabalho é uma necessidade imperativa para desenvolver as potencialidades no modo de produção socialista na URSS, pois as novas condições sociais da organização do trabalho faziam do trabalhador, simultaneamente, trabalhador e dono dos meios de produção.

Neste sentido, a educação, centrada na politecnia "debía de enseñarle como trabajar y organizar la producción, como controlarla y como cuantificarla asi la formación, la cualificación el trabajador debería de ser lo más amplia posible, conforme ensina Krupskaia apud Pérez (s/d: 8), pois:

El obrero no solo tiene que saber operar un torno, sino también conocer el diseño del torno, conocer otros tipos de tornos, cuáles de el los hacen falta para ciertos trabajos, dónde y a qué precio se pueden adquirir tornos mejores, si conviene o no importarlos, si se saca provecho de esto; debe saber hacer el dibujo técnico, hacer cálculos conocer la mecánica y su historia, conocer el comercio. Es preciso que conozca también las propiedades del hierro que trabaja dónde y cómo se produce, en qué condiciones, dónde y cómo puede ser adquirido, etc. Debe estar informado sobre las necesidades de hierro en su país y en otros, de su demanda, saber dónde y cómo vender la producción, computar su costo, etc.

O esforço desprendido por Krupskaia está na necessidade que a URSS tem para se edificar de forma soberana e desenvolvida materialmente pelo trabalho coletivo do homem socialista. E, para isso, se faz urgente à formação de trabalhadores qualificados para as indústrias soviéticas. Por isso, a emergência de uma educação centrada na politecnia e, assim, desenvolver as forças produtivas e promover o desenvolvimento industrial da URSS.

Não é por acaso que Pérez (s/d: 9), ao estudar as obras de Krupskaia, afirma que:

El desarrollo científico y tecnológico (decía) propicia una integración, un acercamiento de los sectores tradicionalmente aislados de la producción industrial y agrícola, lo cual permite revelar no únicamente sus bases científicas y tecnológicas, sino también las económicas y sociales que les 
son comunes. Conocimiento que compone esencialmente un pilar de la educación politécnica. A partir de este contenido los escolares estarían en condiciones de comprender en lo general la actividad productiva, sus regularidades; base sobre la cual podrían participar en cualquier proceso de trabajo. Sin embargo para que estos procesos no resultarán lejanos y/o ajenos a los educandos, toda actividad ligada a la educación politécnica tendría que "sintetizarse y aplicarse en forma creativa en un trabajo productivo, puessin (esta vinculación la educación politécnica) adquiereun carácter contemplativo, verbal".

A escola única do trabalho, para Pistrak, tem por objetivo, ensinar a organizar cientificamente o trabalho para aumentar sua produtividade e dar melhor gerenciamento ao setor administrativo, mas sem ter o caráter de classe existente no ocidente capitalista. Neste sentido, os princípios da "organização científica do trabalho", na escola do trabalho, é um instrumento de libertação de classe, pois a mesma só pode se realizar "de baixo para cima, [...] como meio de consolidar o que já realizamos em termos de revolução social" (PISTRAK, 2003: 81). "A escola do trabalho deve ensinar todo mundo a trabalhar. Portanto, deve cuidar-se não só de fazer assimilar as matérias ensinadas por meio do trabalho, mas também ensinar às crianças o trabalho como tal" (LUNATCHARSKI, 2002b: 07).

Por isso, Lunatcharski (2002b: 06), colocou a primazia do trabalho quando afirmou em seu discurso que:

Consideramos o trabalho como matéria de estudo, isto é, como ensino da técnica no seu conjunto. Consideramos o trabalho também como meio de educação, porque sabemos que é só pelo trabalho coletivo que podemos formar os traços de caráter indispensáveis a uma personalidade sólida e espiritualmente valiosa. Consideramos o trabalho também como participação dos adolescentes e das crianças no processo geral do trabalho da população. A criança deve compreender que o trabalho não é uma brincadeira, mas o elemento no qual se funda a sociedade; deve sentir-se um pequeno trabalhador no grande processo da cooperação. Mas não podemos permitir que esta cooperação não seja parcimoniosa. Manteremos neste trabalho um caráter que permita cuidadosamente construir a partir de um pedaço de pequeno homem um grande trabalhador da sociedade socialista.

Neste sentido, a lógica da educação é aproximar o ensino do trabalho em seus vários ramos de atividade produtiva para formar o homem do trabalho, isto é, o homem politécnico. O homem politécnico é, aqui entendido como aquele que possui os domínios dos fundamentos científicos das diferentes técnicas utilizadas na produção moderna, conforme nos ensino Saviani (2007: 161). Isto posto, a educação politécnica deve concentrar-se "nas modalidades fundamentais que dão base à multiplicidade de processos e técnicas de produção existentes". Trata-se, portanto, "da união entre formação intelectual e trabalho produtivo" (SAVIANI, 2007: 162).

Não é por acaso que Frigotto (1989: 25-26) afirma que "a combinação entre trabalho produtivo manual e trabalho intelectual, geral e politécnico permite à criança, ao jovem e ao adulto construir as bases científicas do processo de produção, bases estas que, são, as que forma o cidadão para construir, a sociedade socialista". Este processo se dá na formação do homem dentro de um quadro de politecnia, para que o mesmo tenha uma cultura geral do trabalho e possa se adaptar às mudanças constantes nas técnicas de produzir. Assim, a escola única do trabalho cumpre com sua função social de formar um trabalhador omnilateral para a sociedade do trabalho, pois "a cultura técnica (formação 
geral e técnica) constituiria a base da autonomia do operariado no processo de produção, com o ensino politécnico preparando o operário para atuar tanto no processo administrativo como, também, no produtivo" (LOMBARDI, 2011: 106). "A escola deve habituar o homem a trabalhar, deve inculcar nele métodos de uma abordagem justa deste mistério que é o mundo; [...]" (LUNATCHARSKI, 2002b: 19).

E como deve ser o trabalho na Escola? Pistrak (2003: 38), responde:

O trabalho na escola, enquanto base da educação, deve estar ligado ao trabalho social, à produção real, a uma atividade concreta socialmente útil, sem o que perderia seu valor essencial, seu aspecto social, reduzindo-se, de um lado, à aquisição de algumas normas técnicas, e, de outro a procedimentos metodológicos capazes de ilustrar este ou aquele detalhe de um curso sistemático. Assim, o trabalho se tornaria anêmico, perderia sua base ideológica.

Não é por acaso que Krupskaia traduz a necessidade do desenvolvimento das potencialidades do trabalho frente à industrialização crescente da URSS ao indagar o que pode ensinar uma escola de fábrica? Para expor seu método de ensino, ela traz o exemplo de uma fábrica têxtil, onde estão presentes a geografia, a história, o desenho industrial, a química, a estrutura física da fábrica, etc. Portanto, os elementos essenciais para o desenvolvimento do processo de ensino, tendo como eixo uma unidade produtiva. Assim, trabalho e educação se complementam no processo de formação do homem, pois toda a estrutura de funcionamento da fábrica será objeto de ensino.

Neste sentido, Krupskaia (s/d: 164) afirma que:

No ensiñará a tejer o hilar a mano o com máquinas, pero los muchachos aprenderán mucho de lo que es necessário saber em la producción. Ante todo, les dará a conocer el papel que desempeña la industria têxtil em la economia del mundo enterro y em la de nuestro país. Les dará a conocer como se desarrollará esta industria em la URSS. Los alunos sabrán donde se encuentran los centros de nuestra industria têxtil, qué matérias-primas utilizan las fabricas - lino, algodón, lana, seda, seda artificial, etc -, donde se encuentran las zonas productoras de estas matérias primas y como se desarrollarán em um futuro próximo. Conocerán las peculiaridades de las matérias primas y los métodos más perfectos de obtenerlas y conservarlas, asi como la instalación de las fabricas, las particularidades de su estrutura, las distintas ramas de la fabricación de tejidos. También sabrán qué profisiones se necesitan em la fábrica. Estudiarán la construcción de las máquinas textiles, aprenderán a disenãr estas máquinas y sabrán la historia del desarrollo de la producción têxtil y em qué consisten los perfeccionamientos modernos. En talleres especiales trabajarán em máquinas de distintos tipos, verán em qué aventajan las máquinas nuevas a las máquinas viejas y aprenderán a atenderlas, cuidarlas y ponerlas em movimiento: empezando por el trabajo a mano y terminando por la electricidad.

Por isso, "a primeira concepção do princípio do trabalho é a de que a criança deve instruir-se por meio do trabalho, isto é, por métodos vivos, ativos" (LUNATCHARSKI, 2002b: 06). Portanto, de experiências reais no mundo do trabalho. De vivências no cotidiano da fábrica, isto é, como um trabalhador, não como um "mero" espectador do mundo real. Neste aspecto, as fábricas deverem cumprir um papel essencial na produção e desenvolvimento do conhecimento, proporcionando ao ser do trabalho uma formação omnilateral, consolidada pela educação politécnica, sendo alicerçada na educação intelectual e física. 
Para finalizar, encerro com as palavras de Lunatcharski (2002b: 12), que chama a atenção dos educadores no I Congresso de Toda a Rússia para a Instrução Publica, sobre a escola única do trabalho, que aqui cito:

Lembrais-vos desse plano. Era o plano de instalação da escola única politécnica do trabalho. A escolaúnica tal como os comunistas a concebem consiste em suprimir qualquer fosso entre a escola de classe para os trabalhadores das camadas sociais inferiores e a escola de classe privilegiada para as crianças das camadas médias e superiores. A escola deve ser única para toda a população no sentido jurídico, no sentido do nível de instrução ao qual cada criança tem direito.

\section{Conclusão}

A escola única do trabalho na Rússia revolucionária foi uma tentativa de organizar a sociedade para a emancipação humana, através da formação omnilateral do homem. $\mathrm{O}$ esforço de Lunatcharski, Krupskaia, Pistrak, etc, foi o de desenvolver uma educação do trabalho. Uma educação voltada aos interesses dos trabalhadores, por isso, uma escola única do trabalho. Mas, a emergência da escola também foi uma necessidade primaria para desenvolver as forças produtivas na URSS e consolidar a república do trabalho.

As experiências e as lutas desenvolvidas na sociedade soviética para a construção da escola única do trabalho não esgotaram a pedagogia dos pioneiros da educação socialista, onde, por vezes, as resistências apareciam e os sinais do esgotamento eram visíveis, pois a cobrança do partido era constante. Construir do nada a escola socialista do trabalho e consolidar a república socialista exigiam dos revolucionários uma constante vigilância, pois os inimigos de classe ainda não estavam totalmente vencidos. Desenvolver as forças produtivas para a produção da vida material (reino das necessidades) e a omnilateralidade do homem emancipado (reino da liberdade) foram perseguidas com entusiasmo pelos construtores da escola única do trabalho, mas o projeto ficou inconcluso e a materialidade da escola única do trabalho, idealizada pelos seus construtores, foi derrotada pela burocracia do estado.

Portanto, a escola única do trabalho enfrentou fortes resistências no interior do magistério russo, mas as práticas pedagógicas desenvolvidas para sua construção permanecem válida, apesar da reforma educacional realizada na década de 1930.

\section{Referências}

FRIGOTTO, Gaudêncio. Trabalho-Educação e tecnologia: treinamento polivalente ou formação tecnológica. In. Educação \& Realidade. V. 14. nº 1, Janeiro/junho de 1989.

- Teoria e práxis e o antagonismo entre a formação politécnica e as relações sociais capitalistas. In. Trabalho, Educação e Saúde. V. 7. Rio de Janeiro, 2009. P. 67-82.

GARAUDY, Roger. Karl Marx. Rio de Janeiro: Zahar Editores, 1967.

LENIN, V. I. Sobre a Educação (a). Vol. 1. Lisboa: Seara Nova, 1977. . Sobre a Educação (b). Vol. 2. Lisboa: Seara Nova, 1977.

LODI-CORRÊA, Samantha; JACOMELI. Krupskaia: revolucionária e educadora. In. www.histedbr.fae.unicamp.br/acer_histedbr/.../V2AFaquF.doc. Acesso em 23/05/2012. 
LOMBARDI, José Claudinei. Educação e Ensino na obra de Marx e Engels. Campinas, SP: Editora Alínea, 2011.

LUNATCHARSKI, Anatoli. A Educação na Rússia Revolucionária (a). Jornal Livro. V. I, $\mathrm{n}^{\circ} 10$. Outubro de 2002.

$\mathrm{n}^{\circ} 10$. Dezembro de 2002.

. A Educação na Rússia Revolucionária (b). Jornal Livro. V. II,

. Decreto sobre la a educación popular. In.

http://marxists.org/espanol/lunacha/obras/1917-11-11.htm. Acesso em 15 de maio de 2012.

KRUPSKAIA, Nadezhda. Acerca de laeducación comunista: Articulos y discursos.

Edicionesenlenguasextranjeras. Moscú, s/d.

. La unión de la juventude. Jornal Pravda, de 27/05/1917. In.

http://marxists.org/espanol/krupskaya/1917/mayo27.htm. Acesso em 15 de maio de 2012.

. La lucha por lajuventudobrera. Jornal Pravda, de 30/05/1917. In. http://marxists.org/espanol/krupskaya/1917/mayo30.htm. Acesso em 15/05/2012.

PÉREZ, Samuel Ubaldo. La educación politécnica vseducación polivalente una discusión pedagógica. In. http://www.fchst.unlpam.edu.ar/iciels/077.pdf. Acessado em 23 de maio de 2012.

PISTRAK, Mikhaylovich. Fundamentos da Escola da Trbalho. $3^{\text {a }}$ Ed. São Paulo: Expressão Popular, 2003.

MARX, Karl; ENGELS, Friedrich. O Partido de Classe II - problemas de organização: Karl Marx e Friedrich Engels (seleção, introdução e notas de Roger Dangeville). Porto, Portugal: Publicações Escorpião, 1975.

SAVIANI, Dermeval. Trabalho e educação: fundamentos ontológicos e históricos. In Revista Brasileira de Educação. V. 12. N 34. Janeiro/Abril, 2007.

Pedagogia histórico-crítica: primeiras aproximações. 11. Ed. Rev.

Campinas, SP: Autores Associados, 2011.

Recebido em julho-12

Aprovado em fevereiro-13 